\title{
WILD LIFE AND ITS PROTECTION IN ANGOLA
}

\author{
By S. Newton Da Silva
}

In spite of the considerable economic development of the last twenty-five years, and hence the occupation and "miseen-valeur" of large formerly unexplored areas and the intensification of motor car traffic in consequence of the opening of new roads, Angola is still a country with plenty of game. Game abounds especially in the southern part with its extended savannas. Certain areas, still little explored and thus still undisturbed along the Rivers Cunene and Cubango (Okavango), for instance, are known as exceptionally rich in game.

Hunting has considerably increased in recent years, due in part to growing transport facilities and in part to increasing demand for game meat and hides as a consequence of this economic development.

The present game law of Angola dates from 1942, and shows remarkable improvement on former laws and regulations regarding the protection of wildlife. It goes so far as to make professional hunting and the trade in game products practically impossible, except for those of a small number of animals as rabbits, warthogs, otters, crocodiles, carnivores and elephants. In certain circumstances, where it is a question of feeding agricultural workers in regions without facilities in obtaining cattle meat, the law permits, as an exception, the shooting of game for this sole purpose.

The law however is still considered inadequate and the Government of Angola has announced already its revision, a new law being expected within the next few months.

Like in other territories of Africa, also in Angola a certain pressure from purely economically interested circles was exercised towards obtaining greater hunting facilities from the Government. So, for instance, based upon what had been alleged by cattle breeders and some commercial circles of Huila, a province in South Angola, the Government about two years ago lifted the severe restrictions, on experimental grounds, for a period of three years, and hunting became a practically not restricted enterprise in that province. Now, however, hardly two years having passed by, the Government made known already that these facilities are going to be immediately revoked, because the outcome has been that not so much the interests of the cattle breeders were involved as the greed of gain of those who sought in hunting an easy way of making a living, regardless 
of whether there was or not the risk of exterminating valuable species of animals.

In this connection it is known for certain that the Government is going to prohibit very soon the import of rifles cal. $\cdot 22$ long and their use for hunting. These rifles will be confiscated if worn outside urban limits and used for any other than target shooting purpose. Such drastic measures have become necessary as otherwise an efficient control of their use is next to impossible. The $\cdot 22$ rifles have been employed even for hunting big animals which more often than not are only deadly wounded and left to perish somewhere in the wilderness.

All this shows that the Government of Angola follows the hunting and game protection very closely, and also the public is taking an interest in it in the same sense. So, for instance, a society for the protection of wildlife in the district of Moçâmedes has been founded, and benefits the co-operation of influential members and the support by the Authorities. It is to be expected that the example Moçâmedes is giving will be followed in other parts of the country, and that a series of similar local societies will very soon watch and care for the conservation and protection of the game in their districts.

There are seven game reserves in Angola, and if in one or other of them there is still want of strict organization and supervision, in most of them very satisfactory results have been secured already.

First, there is the reserve of Quiçama, south of S. Paulo de Luanda, where dwarf forest buffaloes (Syncerus nanus) and elands are abundant, and where one finds lions and numerous herds of elephants. Since this reserve was created the number of elands has grown prodigiously, and concentrations of more than 1,000 of these superb antelopes have been observed there.

The reserve of Luando, in the centre of Angola, cares exclusively for the protection of the giant sable (Hippotragus niger variani), and hunting these animals is strictly prohibited. Hunting permits are granted only in very special cases and for scientific purposes only. Thanks to these severe restrictions their number has considerably increased.

The reserve of Egito, north of Lobito, is rich in elephants, elands, and kudus, and the reserve of Milando, in the region of Malange, known for its wealth in antelopes, has been created in compliance with public request.

The reserve of Cameia, the most eastern of the seven reserves, is a gencral reserve, exceptionally rich in gnus and antelopes as well as in bonte-quaggas. 
In the reserve of Mupa, between the Rivers Cunene and Cuvelai, there are, besides large herds of elephants and zebras, a great variety of antelopes, and still a respectable number of giraffes and black rhinoceroses.

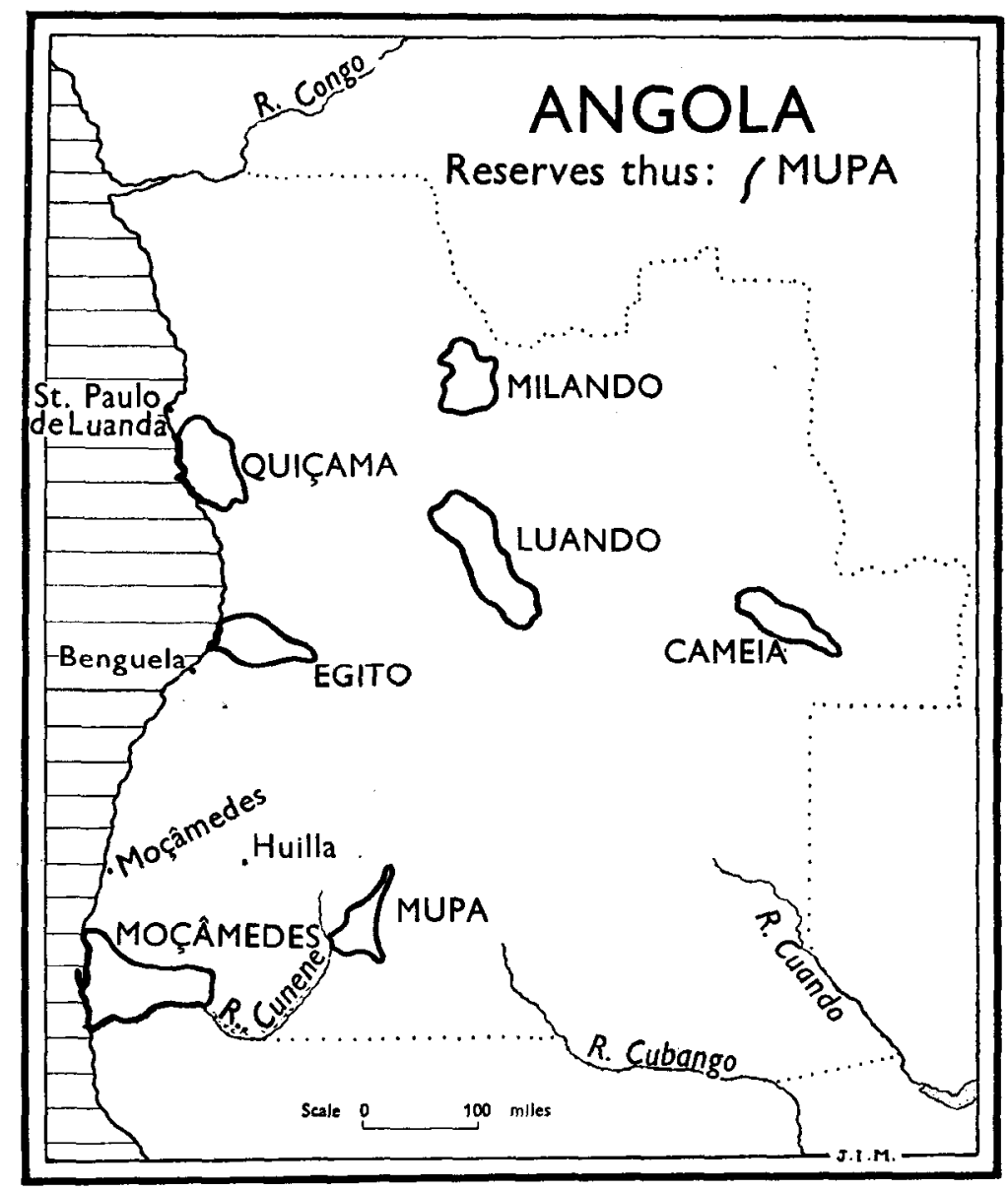

Last not least there is the reserve of Moçâmedes, in the north of the Lower Cunene, protecting the still abundant black rhinoceros and the Hartmann's zebra. There are several elephant herds too, and an overwhelming wealth in springboks, gemsboks, and lions.

The Hartmann's zebra is also at home in the coastal belt south of Benguela, and shooting is everywhere rigorously 
prohibited. Notwithstanding these restrictions, the Society for Game Protection of Moçâmedes presented a memorial for a still more severe control of just these zebras, because recently ruthless and ignorant killers who neither know how nor care to distinguish the Hartmann zebra from the bonte-quagga, have done much harm to those. It is the firm belief, however, that by efficient protection of these animals, and severe fines for any violation of the law, their number will be brought back again without much difficulty and before long to a respectable figure, and the danger of extermination safely removed.

The elephant is still rather abundant in Angola, to such an extent really that in certain regions it becomes sometimes imperative to facilitate shooting. In the dense forests of the Congo region, due to their protection by nature, there are plenty of them, and the natives dedicate themselves very little, if at all, to hunting them. As pointed out already, there are elephants in the regions of Quiçama, south of S. Paulo de Luanda, and several others of the interior of Benguela, and practically everywhere in the south of Angola. As civilization spreads they will move away from the one or other of such regions, but there are so many zones not yet thoroughly explored that there is no danger of extermination for the next hundred years.

The black rhino, on the other hand, although still abundant in the district of Moçâmedes, the region of Mupa, and certain arcas in the south-east of Angola, tends to decrease in number, and it is hoped that hunting these animals will be controlled morc closely in future.

As to the white rhino, the existence of which in the extreme south-east of Angola, in the Cuando, was reported by Schulz and Hammer, and later by Zukowsky and Mattenklodt, not the slightest concrete proof of its survival in those distant regions could be delivered since, so all fear is justified that this species is entirely extinct now. Rumours circulated once that it had appeared in a very narrow area of difficult access in the south of the district of Moçâmedes, near the Cunene border, but so far no proof of it could be secured.

The Society for Protection of the Wildlife in the District of Moçâmedes is going to secure from the Government the prohibition of hunting two species only here existent in very small number, viz.: the silver-backed fox (Vulpes chama) and the long-eared fox (Otocyon megalotis). 